\title{
Działalność czasopisma „Novorečje" na tle serbskich i polskich badań nad neologizmami
}

\begin{abstract}
Mirocha Piotr, Działalność czasopisma ,Novorečje” na tle serbskich i polskich badań nad neologizmami (The Journal "Novorečje" in the Context of Serbian and Polish Studies of Neologisms). "Poznańskie Studia Slawistyczne" 19. Poznań 2020. Publishing House of the Poznan Society for the Advancement of the Arts and Sciences, Adam Mickiewicz University, pp. 429-443. ISSN 2084-3011.

The paper presents the activity of a new Serbian journal "Novorečje" dedicated exclusively to neologisms in language. Analyses disseminated in this periodical are discussed in the context of the approaches to new vocabulary elaborated in the framework of Serbian linguistics. Parallels and divergences with respect to Polish linguistic tradition are also presented. Finally, the paper tries to summarise main research tendencies represented by the authors publishing in the journal "Novorečje": analyses of new feminatives, discussions on derivative mechanisms, neosemantisms, semantic drives, phraseological innovations, lexemes denoting new phenomena, as well as methodological problems.
\end{abstract}

KEYwords: neologisms; vocabulary; lexicography; Slavic studies; Serbian studies

\section{Wprowadzenie}

Serbskie czasopismo „Novorečje” działa od 2019 roku i poświęcone jest wyłącznie badaniom nad neologizmami. Jego charakter określony został w pierwszym numerze przez redakcję jako popularnonaukowy. Wydawane są zarówno teksty wcześniej niedrukowane, jak i takie, które ujrzały światło dzienne w ramach innych publikacji - przewagą czasopisma „Novorečje” jest otwarty dostęp do jego treści via Internet. Artykuły poświęcone są w podobnym stopniu nowym formom wyrazowym, co ewolucji treści pojęciowej odpowiadającej bardziej już utrwalonym jednostkom leksykalnym. Poruszane są również kwestie metodologiczne 
związane z poszukiwaniem możliwie najlepszych sposobów badania neologizmów.

Celem niniejszego tekstu jest przybliżenie aktualnych badań prowadzonych nad neologizmami i prezentowanych na łamach czasopisma „Novorečje". Rzecz zostanie przedstawiona w szerszym kontekście serbskich dociekań nad nową leksyką w języku i ujęta porównawczo w odniesieniu do nauki polskiej.

\section{Czasopismo „Novorečje”}

Stworzone w 2019 roku „Novorečje” nie otwiera serbskich dociekań dotyczących neologizmów w języku - jest z jednej strony summą dotychczasowych osiągnięć, a z drugiej konieczną próbą dotrzymania kroku temu nieustannie rosnącemu polu badań. W skład redakcji wchodzą redaktor naczelny Dejan Ajdačić, a także redaktorzy Đorđe Otašević, Slobodan Novokmet oraz Jovana Jovanović. Swój wkład pozostawili także tacy autorzy jak Aleksandar Milanović (Milanović, Ajdačić, Otašević, 2019), Rajna Dragićević (2020), Vesna Đorđević czy Marina Nikolić (Otašević, Đorđević, Nikolić, 2020).

Choć czasopismo publikuje praktycznie wyłącznie artykuły naukowe, to posiada ono misję następująco definiowaną przez redakcję:

Радујемо се језички обдареним саговорницима који лепим речима богате српски језик чувају његов дух са жељом да га пренесу и будућим поколењима.

Ми смо отворени за нове појаве и речи, али нам није потребна свака гласовно неприкладна страна реч ако можемо да је заменимо неком лепшом речју (Načela «Novorečja», 2019, 1).

(Cieszymy się z lingwistycznie utalentowanych użytkowników języka, którzy wzbogacają serbszczyznę pięknymi słowami i podtrzymują jej duch, chcąc go przekazać również przyszłym pokoleniom.

Otwarci jesteśmy na nowe zjawiska i słowa, ale nie potrzebujemy każdego fonetycznie nieprzystosowanego wyrazu obcego, jeżeli możemy go zastąpić jakimś piękniejszym słowem $)^{1}$.

\footnotetext{
${ }^{1}$ Ten i kolejne przekłady cytatów - P. M.
} 
Nie oznacza to jednak, że badania prezentowane na łamach Novorečja mają charakter purystyczny ${ }^{2}$ czy też że przeważa w nich nurt preskryptywistyczny ${ }^{3}$. Przeciwnie, dużo miejsca poświęca się misji opisu wszystkich tych zjawisk leksykalnych, które w ostatnim czasie stają się częścią serbskiego uzusu.

Owo deskryptywne podejście widoczne jest zresztą w układzie rubryk czasopisma. Mianowicie, stałym elementem - oprócz obszernego działu Članci (Artykuły) - jest dział Građa (Materiały) otwarty na obserwacje neologizmów, a dotąd przedstawiający nowe hasła do Rečnika novih reči (Słownika nowych słów) Đorđa Otaševicia i współpracowników (Đorđević, Nikolić, Otašević, 2019; Otašević, Đorđević, Nikolić, 2020). Ponadto w ramach rubryki Ponovo objavljujemo (Publikujemy ponownie) przedrukowywane są wcześniejsze opracowania dotyczące neologii. Okazjonalnie pojawiają się także sprawozdania $\mathrm{z}$ wydarzeń naukowych związanych z badaniami nad nową leksyką, takich jak dyskusja o najnowszych tendencjach użycia neologizmów w serbszczyźnie, która miała miejsce 29 stycznia 2019 w Bibliotece Uniwersyteckiej „Svetozar Marković” w Belgradzie (Milanović, Ajdačić, Ostašević, 2019).

Jeżeli artykuły mają charakter normatywny - czy raczej: gdy pojawiają się w nich zalecenia - to autorzy próbują przedstawiać argumenty lingwistyczne, które mogłyby je popierać. Przykładem takiego stanowiska są prace Jovany Jovanović dotyczące feminatywów w języku serbskim (Jovanović, 2020a; 2020b). Językoznawczyni ta co do zasady jest przekonana, że żeńskie nazwy wykonawczyń zawodów nie są obce systemowi serbszczyzny. Argumentuje jednak, iż użycie danego leksemu feminatywnego powinno odpowiadać zmianom w rzeczywistości pozajęzykowej, a więc feminizacji danego zawodu.

${ }^{2}$ „Przez puryzm językowy rozumie się na ogół przesadną troskę o język, wynikającą z przesłanek emocjonalnych, a nie racjonalnych. Jest to dbałość o «czystość języka» (łac. purus - 'czysty'), dążenie do usuwania z niego (lub - w wersji mniej skrajnej - niedopuszczania do niego) takich elementów, zwykle leksykalnych, które uznaje się za niepożądane" (Markowski, 2005, 126-127). Najbardziej znaną i rozpowszechnioną odmianą puryzmu jest puryzm nacjonalistyczny. W myśl tej postawy „czystość języka utożsamia się z rodzimością jego elementów, w gruncie rzeczy zaś z rodzimością słownictwa” (Markowski, 2005, 127).

${ }^{3}$ Preskryptywizm rozumiany jest jako termin synonimiczny wobec ,inżynierii językowej” (v. np. Rusiecki, 1994). 


\section{3. „Novorečje” na tle serbskich badań nad neologizmami}

Jak już wspomniano, nowe słowa w języku serbskim badane były już wcześniej. Rozmaite nurty tego rodzaju dociekań zwięźle przedstawia Đorđe Otašević w swym artykule Nove reči $i$ njihovo beleženje (Nowe słowa i ich notowanie; Otašević, 2020). Najistotniejszą rolę odgrywały do tej pory słowniki neologizmów. Najstarszym wydawnictwem był leksykon Jovana Ćirilova (Rečnik novih reči; Ćirilov, 1982; 1991 - dwa wydania). Podobny słownik przygotował również znany lingwista Ivan Klajn (Rečnik novih reči; Klajn, 1992). Publikację tego rodzaju zredagował wreszcie również Đorđe Otašević (2004; 2005; 2008a).

Duże możliwości śledzenia nowych kierunków rozwoju jednostek leksykalnych w języku dają wyspecjalizowane czasopisma. Przykłady tego rodzaju wydawnictw Otašević podaje dla języka rosyjskiego czy francuskiego. Do czasu uruchomienia „Novorečja” podobnych publikacji w Serbii nie było. Aktualny stan leksyki można również śledzić w ramach nowych wydań słowników, tomów uzupełniających wielotomowe słowniki deskryptywne czy wręcz w ramach słowników dwujęzycznych. Podobną funkcję mogą pełnić słowniki terminologiczne, jako że to właśnie żargon profesjonalny należy do najszybciej rozwijających się domen leksykalnych. Neologizmy nieraz pojawiają się także w ramach tzw. słowniczków aneksowych, gdzie czytelnikom artykułów objaśniane są wyrazy o znacznym stopniu specjalizacji, egzotyzmy i właśnie leksyka nowa. Inną możliwością jest odnotowywanie słów nowych i nieznanych szerszej publiczności w tym, co Otašević określa mianem „słowników przeglądowych" - w ramach ściśle określonych domen semantycznych bywają one publikowane w czasopismach adresowanych do tłumaczy, takich jak serbski periodyk „Prevodilac” (Otašević, 2020, 70-72).

Otašević dostrzega także potencjał Internetu i stron poświęconych zbieraniu leksyki nowej. Podaje tu przykład witryny štaZnači.com (Otašević, 2020, 72). O możliwościach, jakie Internet otwiera przed badaczami neologizmów, będzie jeszcze mowa we fragmencie streszczającym polskie dociekania dotyczące nowszego słownictwa.

Co do innych naukowych problemów związanych z neologizmami w języku serbskim, to stosunkowo wcześnie postawiono sobie pytania dotyczące odróżnienia neologizmu jako takiego od okazjonalizmu (v. i.e. 
Otašević, 1993). W dalszej kolejności kwestie precyzyjnych definicji Đorđe Otašević próbował rozwiązywać na podstawie obszernego przeglądu literatury lingwistycznej, przede wszystkim serbskiej i rosyjskiej. Zauważa on podobnie zresztą jak lingwiści polscy - że termin neologizm jest zwykle definiowany bądź zbyt wąsko, bądź zbyt ogólnie, bądź nadmiernie szeroko. Sam wyróżnia kilka parametrów wyróżniających neologizmy, spośród których ,prvi i osnovni [...] je vreme” (pierwszym i podstawowym [...] jest czas; Otašević, 2008b, 40) w odniesieniu do jakiegoś wcześniejszego etapu rozwoju języka. Drugim z parametrów jest „,przestrzeń użycia”, tj. przynależność do języka standardowego, nie zaś do żargonu czy też idiolektu (w odróżnieniu od okazjonalizmów) (Otašević, 2008b, 41). Ostatnią z wymienianych cech neologizmów jest ich ,nowość" - a więc to, pod jakim względem jednostka leksykalna może być nowa. Otašević wspomina tu formy wyrazowe, ale także znaczenia, idiomy oraz prefikso- i sufiskoidy (Otašević, 2008b, 41). Jak będzie jeszcze można zauważyć, wiele z pytań stawianych przez językoznawców serbskich, bliskich jest kwestiom równolegle pojawiającym się w lingwistyce polskiej.

Zagadnienia terminologiczne poruszane są zresztą także w ramach szerzej pojmowanej leksykografii i studiów nad leksyką (v. np. Dragićević, 2018). Okazjonalnie pojawiają się również studia, które leksykę nową badają w ujęciu porównawczym (v. np. Marić, 2007).

Mówiąc o serbskich badaniach nad neologią, wspomnieć też należy pokrewne pola badawcze. Należą do nich studia nad żargonem, a także tzw. miejska etnolingwistyka. W tym miejscu warto poświęcić parę słów rozumieniu pojęć żargonu i slangu. W polskiej socjolingwistyce przyjęło się uważać, że to pierwsze ,,[w] podstawowym znaczeniu eksponuje [...] cechę tajności i kastowości" (Grabias, 1997, 140). Z drugiej strony, istnieją tendencje do rozszerzania znaczenia pojęcia żargonu na wszystkie socjolekty. Pojęcie slangu w literaturze polskiej jest stosunkowo młode - zostało ono zaszczepione z języka angielskiego, gdzie odnosi się do „tych odmian języka, które powstają w środowiskach młodzieżowych i są wynikiem spontanicznej twórczości językowej o charakterze ekspresywnym” (Grabias, 1997, 141).

Z perspektywy terminologii polskiej badania nad żargonem w języku serbskim należałoby zatem określić raczej dociekaniami dotyczącymi slangu. Największą w nich rolę odgrywają rozmaite słowniki skupione przede wszystkim na charakterystyce języka Belgradu - Rečnik savremenog 
beogradskog žargona (Gerzić, Gerzić, 2000) oraz Beogradski frajerski rečnik (Imami, 2000), a także dwujęzyczny angielsko-serbski - Dvosmerni rečnik srpskog žargona i žargonu srodnih izraza (Andrić, 2005). Monografię poświęconą slangowi wydał również Ranko Bugarski (2003).

Badania tego ostatniego skupiają się jednak przede wszystkim nad jednym konkretnym aspektem leksyki slangowej, a mianowicie tzw. amalgamatami leksykalnymi, zwanymi niegdyś w językoznawstwie polskim kontaminacjami słowotwórczymi ${ }^{4}$. Sam Bugarski wykorzystuje termin ukuty przez Ivana Klajna slivenica. Wyrazy takie definiuje jako:

leksičk[e] blend[e] koje nastaju procesom slivanja „dveju reči ili njihovih delova u novu celinu, često ali ne i obavezno motivisanim preklapanjem njihovih formalnih segmenata, pri čemu tako dobijena tvorenica najčešće i semantički predstavlja kombinaciju delova koji su ušli u njen sastav" (Bugarski, 2018, 145).

(amalgamaty językowe, które powstają w wyniku procesu zlewania się „dwóch wyrazów lub ich części w nową całość, często, ale nie koniecznie, motywowanego nakładaniem się ich segmentów formalnych, przy czym tak otrzymany twór zazwyczaj również semantycznie stanowi kombinację części, które weszły w jego skład”).

Zdaniem Bugarskiego tego rodzaju leksykę najczęściej można odnaleźć w żargonie młodzieżowym, nazwach instytucji dla dzieci, mediach zwłaszcza elektronicznych, reklamach, dyskursach politycznych, nazwach instytucji, festiwali, wystaw, stowarzyszeń, projektów, tytułach książek, a także w języku dzieci, etymologii ludowej, lapsusach czy grach słów. Tego rodzaju zjawiska leksykalne lingwista ów notuje konsekwentnie w swoich kolejnych publikacjach (Bugarski, 2009; 2010; 2013; 2014; 2016; 2018). Szerszym polem badawczym jest miejska etnolingwistyka uprawiana przez Predraga Pipera (v. i.e. 2008).

\section{Leksyka nowa w językoznawstwie polskim}

Zanim przedstawione zostaną podejścia do neologizmów, które prezentują badacze serbscy na łamach „Novorečja”, należałoby pokrótce omówić to, jak owo pole badawcze uprawiane było w nauce polskiej.

${ }^{4}$ Problematyką amalgamatów słowotwórczych w językoznawstwie polskim zajmowali się m.in. Henryk Kardela (2006) czy Agnieszka Libura (2015). 
Może to pozwolić uniknąć nieporozumień pojęciowych, ale także wskazać na liczne podobieństwa.

Przykładowo, Teresa Smółkowa dokonuje przeglądu licznych definicji neologizmu i wyciąga wniosek z jednej strony o nieusuwalności tego terminu $\mathrm{z}$ aparatu pojęciowego językoznawstwa, z drugiej zaś strony o nadmiernie szerokim jego znaczeniu (Smółkowa, 2001, 11-14). Ostatecznie neologizm zdaniem badaczki to

jednostka leksykalna, nowa pod względem budowy, znaczenia lub połączenia z innymi jednostkami, ustabilizowana w normie leksykalnej całkowicie lub tylko częściowo; neologizm: słowotwórczy, semantyczny (neosemantyzm), frazeologiczny; także nowe zapożyczenie z innego języka (Smółkowa, 2001, 14).

Pojęcie to odgraniczone jest od okazjonalizmu, który w tradycji polskiej i rosyjskiej definiowany jest za Chruścińską (1978) jako „nowy wyraz, który wystąpił tylko w konkretnym tekście" (Smółkowa, 2001, 14). Smółkowa wprowadza także koncepty neologizmów ustabilizowanych i nieustabilizowanych, gdzie te ostatnie to takie, które „występują w kilku różnych tekstach różnych autorów, ale są zbyt rzadkie, aby można uznać je z całą pewnością za leksemy" (Smółkowa, 2001, 14-15). Co do kryterium chronologicznego, w opracowaniu Neologizmy we współczesnej leksyce polskiej ,[z]a współczesne neologizmy uznaje się na ogół wyrazy, które powstały po II wojnie światowej" (Smółkowa, 2001, 24).

Teresa Smółkowa prowadziła badania nad nową leksyką w polszczyźnie w ramach Obserwatorium Językowego Instytutu Języka Polskiego w Polskiej Akademii Nauk. Jednym z rezultatów prac obserwatorium był słownik neologizmów Słowa, słowa... Czy je znasz? (Smółkowa et al., 2013). Do wydawnictwa wciągana była także leksyka, która

jest obecna w słownikach języka polskiego, wydawanych od lat 90. do dziś, ale wyrazy te są rozproszone, niewyodrębnione za pomocą odpowiedniego kwalifikatora, wtopione w całość zawartego w tych słownikach materiału językowego. Zdecydowana większość haseł zamieszczonych w niniejszym opracowaniu nie jest notowana nawet w najnowszych słownikach (Smółkowa et al., 2013, 5).

Zasób leksykalny publikacji „obejmuje wyrazy, które w większości pojawiły się w polszczyźnie w dwóch ostatnich dekadach" (Smółkowa et al., 2013, 5). 
Podstawowymi kryteriami doboru materiału był „czas pojawienia się wyrazów w tekstach prasowych głównie z lat 90. XX wieku i późniejszych oraz częstotliwość ich występowania w Internecie i [...] kartotece" (Smółkowa et al., 2013, 5).

W Polsce istnieje jednak więcej niż jedno podobne przedsięwzięcie. Obserwatorium Językowe funkcjonuje także wśród lingwistów działających na Uniwersytecie Warszawskim. Aktywność tego obserwatorium charakteryzuje wykorzystanie Internetu i otwartość na spostrzeżenia zmian leksyki zgłaszane przez internautów - tzw. crowdsourcing. W ramach witryny nowewyrazy.uw.edu.pl neologizmy wciągane do słownika definiowane są przez szereg kryteriów. Przede wszystkim za takie uznawane są wyrazy, które do polszczyzny weszły bądź po roku 1989 - zdaniem starszego i średniego pokolenia językoznawców, bądź po roku 2000 - według młodszych lingwistów. Za neologizm uznać można nie tylko pojedyncze słowo, lecz całą syntagmę. Ponadto nie jest istotne, czy wyraz jest nowy formalnie, czy też stanowi neosemantyzm (Neologizmy, b.d.). Dodatkowe kryteria to nienotowanie leksemu przez autorytatywne słowniki ogólne języka polskiego i słowniki wyrazów obcych, a także występowanie lub upowszechnianie się w języku ogólnym (Budowa słownika, b.d.).

Leksykę, która pojawiła się w języku po roku 1989, notował również dwujęzyczny polsko-niemiecki Polnisch-deutsches Wörterbuch der Neologismen:

[Im Wörterbuch e]rfasst werden die in einem bestimmten Zeitraum neu aufgekommenen heimischen wie entlehnten Wörter, Wortbedeutungen und festen Wortgruppen. Sie müssen bereits überindividuelle Geltung, messbar an einer gewissen Gebrauchshäufigkeit, erlangt und in die Allgemeinsprache Eingang gefunden haben bzw. Tendenziell auf dem Weg dorthin sein. Dabei ist es unerheblich, ob dieses Neuwort bereits in einem allgemeinen Wörterbuch verzeichnet ist oder nicht, bestimmend ist zunächst der Entstehungszeitraum der letzten fünfzehn bis zwanzig Jahre, d.h. im wesentlichen nach 1989/90. Ausgeklammert wurden rein fachsprachliche und gruppengebundene Lexik sowie offensichtliche Okkasionalismen [...], wie auch bewusst aus Gründen der Expressivität gebildete text- und situationsgebundene Individualismen [...] (Worbs et al., 2007, X).

([W słowniku z]ebrane zostały rodzime i zapożyczone słowa, znaczenia i ustalone syntagmy, które pojawiły się w określonym odcinku czasu. Musiały one już zdobyć charakter ponadindywidualny, mierzalny określoną częstością użycia, a także wejść do języka ogólnego lub być na drodze do tego. Było przy tym nieistotne, czy taki neologizm 
został już zanotowany w słowniku ogólnym, czy też nie - decydujące było natomiast pojawienie się w okresie ostatnich piętnastu-dwudziestu lat, tj. zasadniczo po 1989/90 roku. Pominięta została leksyka czysto fachowa i żargonowa, oczywiste okazjonalizmy [...], jak i związane z konkretnymi tekstami i sytuacjami indywidualizmy, tworzone świadomie dla zwiększenia ekspresji).

Spośród polskich słowników leksyki nowej wymienić należy jeszcze pozycję Nowe słowa autorstwa Jerzego Bralczyka (2007), a także serię wydawnictw współredagowanych przez Andrzeja Bogusławskiego, spośród których najnowszym jest tom Verba polona abscondita. Sonda słownikowa III (Bogusławski, Danielewiczowa, 2005). Te ostatnie jednak nie są słownikami w ścisłym rozumieniu tego słowa - uzupełniają one materiał nieodnotowany $\mathrm{w}$ poprzednich wydaniach $\mathrm{z}$ serii, prezentując nie tylko neologizmy sensu stricto, ale także zakorzenione elementy leksykalne, które nie zostały uwzględnione we wcześniejszych opracowaniach leksykograficznych bądź wyodrębnione lub opisane w błędny sposób. Sami autorzy przyznają, że ich ambicją nie jest stworzenie wyczerpującego słownika. Przeciwnie rejestracja słownictwa ma charakter przygodny, wyrywkowy, gdyż celem jest raczej zaprojektowanie zdyscyplinowanych rozwiązań leksykograficznych (Bogusławski, Danielewiczowa, 2005).

Problemami neologizmów w polszczyźnie zajmowali się także tacy naukowcy jak Beata Nowakowska (2005), Krystyna Waszakowa (2005), Jan Wawrzyńczyk (1992), Piotr Wierzchoń (2008) czy Erika Worbs (2009).

\section{Badania nad neologizmami w czasopiśmie „Novorečje”}

Spektrum tematyczne artykułów w czasopiśmie „Novorečje” jest szerokie. Sporo uwagi poświęca się aktualnemu zagadnieniu, jakim są feminatywy. Kwestię tego, czy nazwy kobiece można z perspektywy semantycznej uznawać za derywowane od nazw męskich, omawia Đorđe Jovanović w artykule Semantičke definicije novih femininuma (Definicje semantyczne nowych feminatywów) (Otašević, 2019a). Tę tematykę rozważa także Jovana Jovanović. Tak w ujęciu holistycznym, jak i na przykładzie leksemu trenerka 'trenerka', autorka ta przedstawia możliwości słowotwórcze 
języka serbskiego w zakresie tworzenia feminatywów, z drugiej zaś strony zauważa istnienie pewnych ograniczeń natury socjolingwistycznej (Jovanović, 2020a, 2020b).

Omawiane są również inne kategorie derywatów słowotwórczych. Slobodan Novokmet chociażby obszernie analizuje neologizmy tworzone przy użyciu sufiksu -ina, który w języku serbskim przeważnie daje augmentativa (Novokmet, 2019a). Rozwój nowych formantów słowotwórczych śledzi Rajna Dragićević na przykładzie formatów -oid '-oid' i -saurus '-zaur'. Rozważania Dragićević są szczególnie interesujące, ponieważ podejmuje ona próbę zarówno komparatywnego ujęcia rozwoju neologizmów, jak i wyciągania wniosków o charakterze prognostycznym. Analizy badaczki stanowią ponadto wkład w teorię słowotwórstwa, klarując różnicę między pojęciami sufiksu i sufiksoidu (Dragićević, 2020). Przedmiotem rozważań autorów piszących do „Novorečja” bywają także innego rodzaju podobieństwa formalne między neologizmami - a mianowicie te dotyczące ich podstaw słowotwórczych. Đorđe Otašević w jednym ze swych artykułów poświęcił uwagę odantroponimicznym neologizmom, które w dyskursie politycznym są nieraz urabiane od nazwisk serbskich polityków, prezydenta Aleksandra Vučicia i działacza Partii Demokratycznej Dragana Đilasa (Otašević, 2020a).

Autorzy publikujący w omawianym periodyku nie ograniczają się jedynie do leksyki, która jest nowa wyłącznie pod względem formy. Przykładem analiz neosemantyzmów w języku serbskim, które powstają pod wpływem języków światowych, jest artykuł Jovany Jovanović Nova upotreba prideva human $u$ savremenom srpskom jeziku (Nowe użycie przymiotnika human we współczesnym języku serbskim; Jovanović, 2019). Autorzy analizują także neologizmy na poziomie frazeologii czyni to na przykład Dejan Ajdačić, badając całe pole nowo powstających frazeologizmów odwołujących się do pola semantycznego sport (Ajdačić, 2019).

Na łamach czasopisma znajduje się miejsce także dla zjawisk z pogranicza neologii, a mogących stanowić przedmiot zainteresowania literaturoznawców. Mowa tu o indywidualizmach pojawiających się u autorów serbskiej awangardy Dimitrije Mitrinovicia i Dragana Aleksicia (Ajdačić, 2020b). Przedmiotem analiz bywają też nowe pojęcia z rzeczywistości pozajęzykowej, którym użytkownicy języka próbują przyporządkować 
możliwie trafne leksemy. Przykładem są tu rozważania nad nazwą 'progu zwalniającego' w języku serbskim, a także chorwackim (Novokmet, 2019b).

Poruszane są wreszcie również kwestie metodologiczne. Đorđe Otašević w swych tekstach zwraca uwagę na możliwie efektywne sposoby śledzenia nowych tendencji w leksyce (Otašević, 2019d), a także metody łagodzenia nieuniknionej niekompletności słowników deskryptywnych (Otašević, 2020b).

Charakter artykułów jest w przeważającym stopniu empiryczny - autorzy wyraźnie preferują konfrontację z materią żywego języka aniżeli spory czysto terminologiczne. Nie znaczy to, że nie są oni świadomi konieczności jasnego definiowania pojęć. Przeciwnie, Đorđe Otašević zauważa na przykład - równolegle do badaczy polskich - że w dziedzinie badań nad nową leksyką narzędzia konceptualne często nie posiadają ścisłych definicji:

Неолошка терминологија, не само српска, није уједначена тако да термине неологизам, неологизам у ужем смислу, нова реч у ужем смислу, оказионализам, узуални неологизам, нормативни неологизам, стандардни неологизам, оказионални неологизам, стилистички неологизам, ауторски неологизам, семантички неологизам, лексички неологизам, лексичко-семантички неологизам, неосемантизам, индивидуализам, индивидуализам-оказионализам, потенцијална реч, кованица, хапакс и др. лингвисти користе у различитим значењима (Otašević, 2020a, 11).

(Terminologia neologiczna - nie tylko serbska - nie jest ujednolicona, toteż terminy neologizm, neologizm sensu stricto, nowe słowo sensu stricto, okazjonalizm, neologizm uzualny, neologizm normatywny, neologizm standardowy, neologizm okazjonalny, neologizm stylistyczny, neologizm autorski, neologizm semantyczny, neologizm leksykalny, neologizm leksykalno-semantyczny, neosemantyzm, indywidualizm, indywidualizm-okazjonalizm, wyraz potencjalny, złożenie, hapaks itd. są wykorzystywane przez lingwistów w różnych znaczeniach).

Rozwiązania tego zawikłanego problemu, które proponują autorzy piszący dla „Novorečja”, mają charakter praktyczny - w swoich badaniach empirycznych uwzględniają przeważnie leksykę nieobecną w najnowszych wydaniach autorytatywnych słowników języka serbskiego. Slobodan Novokmet uwzględnia tu Rečnik srpskohrvatskog književnog jezika Maticy Srpskiej, Rečnik srpskohrvatskoga književnoga i narodnoga jezika Serbskiej Akademii Nauk i Umiejętności (18 dotąd wydanych tomów) 
oraz jednotomowy Rečnik srpskoga jezika Maticy Srpskiej (Novokmet, 2019a, 38). Đorđe Otašević, zbierając materiały do słowników wyrazów nowych, uwzględnia tę ostatnią pozycję oraz dotąd wydane słowniki neologizmów - pod redakcją Ivana Klajna i Milana Šipki (Klajn, Šipka, 2006), a także słownik nowych anglicyzmów w języku serbskim Do you speak anglosrpski? (Vasić, Prćić, Nejgebauer, 2001). Nietrudno zauważyć, że praktyka ta jest podobna do rozwiązań stosowanych w polskich obserwatoriach językowych. W ten sposób autorzy - zarówno serbscy, jak i polscy - unikają jałowych sporów terminologicznych i skupiają na fenomenach pojawiających się w dynamicznie zmieniającym się języku.

\section{Podsumowanie}

Czasopismo „Novorečje” wpisuje się w dłuższą tradycję serbskich badań nad neologizmami w języku. Oferując swoje łamy artykułom poświęconym tej właśnie tematyce, pozwala nadążyć za - zdaniem wielu badaczy - coraz szybciej rosnącym zasobem leksykalnym języka. Przeważające wśród publikowanych tekstów studia empiryczne owocują konkluzjami natury teoretycznej. Wnioski te, skądinąd nierzadko współbrzmiące z ustaleniami językoznawców polskich, mogą być z pewnością interesujące dla slawistów również spoza Serbii. Zdecydowanie warto, by „Novorečju", czasopismu ściśle poświęconemu badaniom nad nową leksyką w języku, swoją uwagę poświęciła międzynarodowa społeczność slawistyczna - może to dać wymierne rezultaty w postaci komparatywnych ujęć najnowszych tendencji w systemoidach leksykalnych języków słowiańskich.

\section{Literatura}

Ajdačić, D. (2019). Sportske komponente u novim srpskim frazeologizmima. „Novorečje" br 1, s. 59-68.

Ajdačić, D. (2020). Autorski neologizmi-individualizmi Dimitrija Mitrinovića (1913) i Dragana Aleksića (1922). „Novorečje” br 2, s. 37-46.

Andrić, D. (2005). Dvosmerni rečnik srpskog žargona i žargonu srodnih izraza. Beograd: Zepter Book World. 
Bogusławski, A., Danielewiczowa, M. (2005). Verba polona abscondita. Sonda stownikowa. III. Warszawa: Elma Books.

Bralczyk, J. (2007). Nowe słowa. Warszawa: Hachette.

Budowa słownika (b.d.) Obserwatorium Językowe Uniwersytetu Warszawskiego. https://nowewyrazy.uw.edu.pl/budowa-slownika.html. 8.07.2020.

Bugarski, R. (2003). Žargon - lingvistička studija. Beograd: Biblioteka XX vek.

Bugarski, R. (2009). Teorijske osnove urbane dijalektologije. W: Evropa u jeziku. Ur. R. Bugarski. Beograd: Biblioteka XX vek, s. 77-102.

Bugarski, R. (2009). Evropa u jeziku. Beograd: Biblioteka XX vek.

Bugarski, R. (2010). Jezik i identitet. Beograd: Biblioteka XX vek.

Bugarski, R. (2013). Sarmagedon u Mesopotamaniji. Beograd: Biblioteka XX vek.

Bugarski, R. (2014). Putopis po sećanju. Beograd: Biblioteka XX vek.

Bugarski, R. (2016). Jezici u potkrovlju. Beograd: Biblioteka XX vek.

Bugarski, R. (2018). Govorite li zajednički? Beograd: Biblioteka XX vek.

Chruścińska, K. (1978). O formach potencjalnych $i$ okazjonalnych. W: Z zagadnień słownictwa współczesnego języka polskiego. Red. M. Szymczak. Wrocław: Ossolineum, s. 69-79.

Ćirilov, J. (1982). Rečnik novih reči, izraza i značenja nastalih u srpskohrvatskom jeziku posle drugog svetskog rata. Beograd: Narodna knjiga.

Ćirilov, J. (1991). Novi rečnik novih reči, izraza i značenja preuzetih iz drugih jezika ili nastalih u srpskohrvatskom jeziku posle Drugog svetskog rata. Beograd: Bata.

Dragićević, R. (2018). Srpska leksika u prošlosti i danas. Novi Sad: Matica srpska.

Dragićević, R. (2020). Neke tendencije u tvorbi reči u savremenom srpskom jeziku. „Novorečje” br 2, s. 129-139.

Đorđević, V., Nikolić, M., Otašević, Đ. (2020). Građa za rečnik novih reči (2). „Novorečje" br 2, s. 61-126.

Gerzić, B., Gerzić, N. (2000). Rečnik savremenog beogradskog žargona. Beograd: Istar.

Grabias, S. (1997). Język w zachowaniach społecznych. Lublin: UMCS.

Imami, P. (2000). Beogradski frajerski rečnik. Beograd: NNK International.

Jovanović, J. (2019). Nova upotreba prideva human u savremenom srpskom jeziku. „Novorečje” br 1, s. 5-8.

Jovanović, J. (2020a). Feminizam u jeziku - noviji nazivi za ženska zanimanja. „Novorečje" br 2, s. 47-50.

Jovanović, J. (2020b). Trenerka i još ponešto. „Novorečje” br 2, s. 55-57.

Kardela, H. (2006). (Nie)podobieństwo w morfologii: amalgamaty kognitywne. W: Kognitywistyka 2. Podobieństwo. Red. H. Kardela, Z. Muszyński, M. Rajewski. Lublin: UMCS, s. 195-210.

Klajn, I. (1992). Rečnik novih reči. Novi Sad: Matica srpska.

Klajn, I., Šipka, M. (2006). Veliki rečnik novih reči i izraza. Novi Sad: Prometej.

Libura, A. (2015). Kagrestkos i brzoskwiśnia. Wybrane problemy zwiazane ze struktura amalgamatów leksykalnych. „Acta Universitatis Wratislaviensis. Języka a Kultura" nr 25, s. 189-200. 
Marić, A. (2007). Neologizmi u slovačkom i srpskom jeziku. „Slavistika” br XI, s. 267-273 .

Markowski, A. (2005). Kultura języka polskiego. Teoria. Zagadnienia leksykalne. Warszawa: Wydawnictwo Naukowe PWN.

Milanović, A., Ajdačić, D., Ostašević, Đ. (2019). Iz razgovora. „Novorečje” br 1, s. $29-31$.

Načela novorečja (2019). „Novorečje” br 1, s. 1.

Neologizmy (b.d.). Obserwatorium Językowe Uniwersytetu Warszawskiego. https:// nowewyrazy.uw.edu.pl/neologizmy.html. 8.07.2020.

Novokmet, S. (2019a). Nove reči sa sufiksom -ina i njegovim varijantama u srpskom jeziku. „Novorečje” br 1, s. 38-54.

Novokmet, S. (2019b). Da li ležeći poliajac spava ili samo leži? „Novorečje” br 1, s. 55-58.

Nowakowska, B. (2005). Nowe połączenia wyrazowe we współczesnej polszczyźnie. Kraków: Lexis.

Otašević, Đ. (1993). Razgraničenje okazionalizama i neologizama. W: Naučni sastanak slavista u Vukove dane 23/2. Beograd: Međurnarodni slavistički centar, s. 251-255.

Otašević, Đ. (2004). Veliki rečnik novih i nezabeleženih reči 1. Beograd: Alma.

Otašević, Đ. (2005). Veliki rečnik novih i nezabeleženih reči 2. Beograd: Alma.

Otašević, Đ. (2008a). Rečnik novih i nezabeleženih reči (sažeto izdanje). Beograd: Alma.

Otašević, Đ. (2008b). Nove reči i značenja u savremenom standardnom srpskom jeziku: Lingvistički aspekt. Beograd: Alma.

Otašević, Đ. (2019a). Semantičke definicije novih femininuma. „Novorečje” br 1, s. $9-10$.

Otašević, Đ. (2019b). Građa za rečnik novih reči (1). „Novorečje” br 1, s. 13-25.

Otašević, Đ. (2019c). Nove reči i njihovo beleženje. „Novorečje” br 1, s. 67-73.

Otašević, Đ. (2020a). Tvorba deantroponimnih političkih neologizama (od prezimena Vučić i Đilas). „Novorečje”, br 2, s. 9-36.

Otašević, Đ. (2020b). Iscrpnost opisnih rečnika. „Novorečje” br 2, s. 140-142.

Piper, P. (2008). O urbanoj etnolingvistici W: Etnolingvistička proučavanja srpskog i drugih slovenskih jezika. U čast akademika Svetlane Tolstoj. Ur. P. Piper, Lj. Radenković. Beograd: SANU, s. 105-122.

Rusiecki, J. (1994). Postawy wobec języka w Anglii i w Stanach Zjednoczonych Ameryki Pótnocnej dawniej i dziś. W: Normalizacja języka w krajach Zachodu. Red. A. Markowski, J. Puzynina. Warszawa: Semper, s. 9-28.

Smółkowa, T. (2001). Neologizmy we współczesnej leksyce polskiej. Kraków: IJP PAN. Smółkowa, T. (red.) (2010-2014). Nowe słownictwo polskie. Materiały z prasy lat 2001-2005, cz. 1-5. Kraków: IJP PAN.

Smółkowa, T., Holly, K., Nowakowska, B., Żółtak, A. (2013). Słowa, słowa... Czy je znasz? Kraków: IJP PAN. 
Vasić, V., Prćića, T., Nejgebauer, V. (2001). Do you speak anglosrpski? Rečnik novijih anglicizama. Novi Sad: Zmaj.

Waszakowa, K. (2005). Przejawy internacjonalizacji w słowotwórstwie współczesnej polszczyzny. Warszawa: UW.

Wawrzyńczyk, J. (1992). Chronologizacja słownictwa nowopolskiego. W poszukiwaniu źródeł dokumentacyjnych neologizmów powojennych. Toruń: UMK.

Wierzchoń, P. (2008). Fotodokumentacja. Chronologizacja. Emendacja. Teoria i praktyka weryfikacji materiału leksykalnego $w$ badaniach lingwistycznych. Poznań: Sorus.

Worbs, E. (Hrsg.) (2009). Neue Zeiten - neue Wörter - neue Wörterbücher. Beiträge zur Neologismenlexikografie und -lexikologie. Frankfurt am Main: Peter Lang.

Worbs, E., Markowski, A., Meger, A. (2007). Polnisch-deutsches Wörterbuch der Neologismen. Neuer polnischer Wortschatz nach 1989. Wiesbaden: Harrasowitz. 